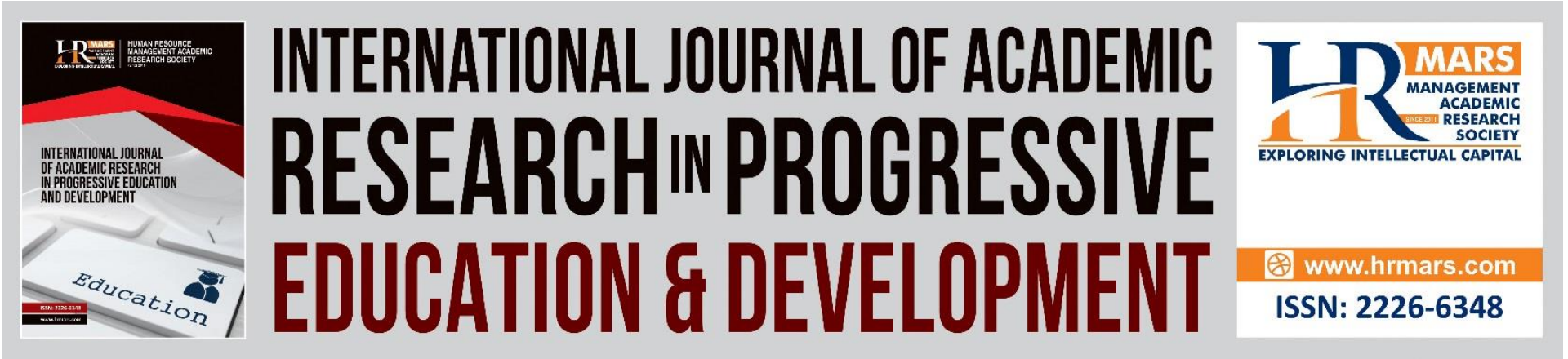

\title{
The Validity and Reliability of Sustainable Leadership Instrument
}

Saraswathy Kullan, Mahaliza Mansor, Rosnah Ishak

To Link this Article: http://dx.doi.org/10.6007/IJARPED/v11-i1/11906

DOI:10.6007/IJARPED/v11-i1/11906

Received: 13 November 2021, Revised: 14 November 2021, Accepted: 28 December 2021

Published Online: 19 January 2022

In-Text Citation: (Kullan et al., 2022)

To Cite this Article: Kullan, S., Mansor, M., \& Ishak, R. (2022). The Validity and Reliability of Sustainable Leadership Instrument. International Journal of Acdemic Research in Progressive Education and Development, 11(1), 155-169.

Copyright: (C) 2022 The Author(s)

Published by Human Resource Management Academic Research Society (www.hrmars.com)

This article is published under the Creative Commons Attribution (CC BY 4.0) license. Anyone may reproduce, distribute, translate and create derivative works of this article (for both commercial and non-commercial purposes), subject to full attribution to the original publication and authors. The full terms of this license may be seen

at: http://creativecommons.org/licences/by/4.0/legalcode

Vol. 11(1) 2022, Pg. 155 - 169

http://hrmars.com/index.php/pages/detail/IJARPED

JOURNAL HOMEPAGE

Full Terms \& Conditions of access and use can be found at http://hrmars.com/index.php/pages/detail/publication-ethics 


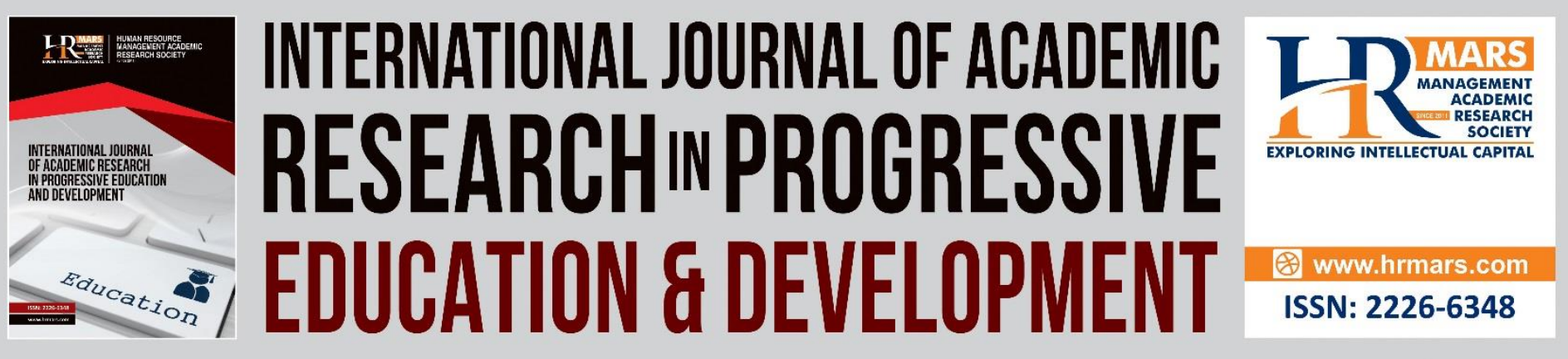

\title{
The Validity and Reliability of Sustainable Leadership Instrument
}

\author{
Saraswathy Kullan, Mahaliza Mansor, Rosnah Ishak \\ Faculty of Management and Economics, Sultan Idris Education University, Perak, Malaysia
}

\begin{abstract}
High-capacity headmasters can certainly make improvements and create effective schools. The main purpose of this study was to report on the validity and reliability of the sustainable leadership instrument. The Sustainable Leadership Questionnaire (SLQ) instrument was used for the validity and reliability of the headmasters' sustainable leadership practices from the teacher's perspectives. The design of this quantitative study involved a total of 6 experts with extensive experience in the field of educational leadership to validate the content and 50 teachers from 4 indigenous primary schools in Negeri Sembilan, Malaysia who were selected using the simple random method in determining the reliability of the instrument. The analytical gains of I-CVI (0.67 to 1.00$)$, S-CVI (0.92 to 1.00) and modified kappa statistic coefficient index $(0.57$ to 1.00$)$ proved that the instrument in this study had high content validity. In line with this, Cronbach's Alpha values, Cronbach's Alpha if Item Deleted, InterItem Correlation and Corrected Item-Total Correlation were utilized to describe that the SLQ instrument in this study had good reliability. Therefore, the SLQ instrument is reliable to measure headmasters' sustainable leadership practices from the teacher's perspectives in the context of indigenous primary schools Malaysia. The study implied that the sustainable leadership practices of headmasters needed to be practised in schools especially in primary schools as headmasters with sustainable leadership values are highly competent and able to maintain the sustainability of schools.
\end{abstract}

Keywords: Headmaster, Sustainable Leadership, Validity, Reliability.

\section{Introduction}

The $4^{\text {th }}$ Sustainable Development Goal (SDG) aims to offer quality education to all (UNESCO, 2018; MOE, 2018). Quality of education plays a role as an agent of change that can reduce the gap of inequality in the socio-economy by eradicating poverty. In addition, equal inclusive education as well as lifelong learning opportunities can transform knowledge, skills, values, attitudes and empower current and future generations to meet the economic, social and environmental balance of life towards achieving quality education (UNESCO, 2018).

In this regard, high quality headmasters should (1) set the strategy and direction of the school in an effort to make positive changes to student and school achievement, (2) monitor and evaluate the professional development of teachers in the school from time to time, (3) regularly motivate teachers under their administration to improve their skills and capacity 
(OECD, 2016), (4) create a conducive school environment based on trust and (5) promote effective communication inside and outside the school as well as (6) adopt a culture structured collaboration among teachers (Li, Hallinger, \& Ko, 2016) to meet the needs of students, teachers, schools, communities and even the country.

Thus, school leadership needs to integrate shared leadership and team performance (D'Innocenzo, Mathieu, \& Kukenberger 2016) as well as school -based network leadership (Leithwood \& Azah 2016). In addition, educational leaders must always focus on the aspect of continuous improvement to improve the quality and effectiveness of education. This is because educators believe that the effectiveness of the leadership among leaders (headmasters) in educational institutions (schools) has an influence on the organization and also its achievements (Mahzan \& Nordin, 2021). Therefore, headmasters should adopt a leadership that creates teachers' trust in themselves, maintaining that trust for a long time in order to motivate teachers to offer quality services and work to achieve common goals (Vikaraman et al., 2021).

Related to this, Dueppen (2017) aimed to investigate the role of sustainable leaders in large-scale reform at the school, district and state levels, which led to changes in systems in the long run. Dueppen reported that principals, teachers and the community had equal responsibility for large-scale educational change. In addition, sustainable leaders are responsible for (1) creating opportunities for continuous deep learning, (2) practising moral purpose by being positive, appreciating and supporting others including students and teachers, (3) practise reform all the time, and (4) trust and work with all parties to achieve educational reformation.

In conclusion, the practices of sustainable leadership among headmasters in schools should be given priority to ensure that the quality of students, teachers and schools can be improved.

\section{Problem Statement}

Headmasters' sustainable leadership practices were found to have direct impact on teachers and their professional practices. Therefore, sustainable leadership practices need to be practiced by headmasters in schools to ensure the existence of a school culture that applies the best practices consistently for the long term (Nagy, 2019). This is because the main responsibility of headmasters in increasingly complex schools is to make positive change in cultures and practices which can enhance teacher capacity in the organizations they lead (Fullan, 2008; 2005; Hargreaves \& Fink 2006).

Related to this, empirical data from Iqbal, Ahmad and Li (2021); Sezgin-Nartgun, Limon and Dilekci (2019) prove that the level of sustainable leadership practices reaches a satisfactory level. Moreover, the concept of sustainable leadership in education needs to be studied comprehensively to find out whether this idea can be fully applied in different situations or not because this concept of sustainable leadership is still in its infancy (Lambert 2011; 2012) and requires extensive literature.

To obtain data in surveys, the questionnaires are often used. Thus, accuracy and consistency of the questionnaire can give a preliminary picture whether the actual study can be continued or vice versa. This phase termed as the validity and reliability of the instrument. Content validity is highly recommended among various methods of validity because it can measure each item accurately (Taherdoost, 2016). Additionally, Cronbach's alpha measurement known as the best approach for measuring the internal consistency of an instrument (Creswell \& Creswell, 2018). In this regard, the researchers conducted this 
DEVELOPMENT

Vol. 11, No. 1, 2022, E-ISSN: 2226-6348 @ 2022 HRMARS

preliminary study to obtain information on the validity and reliability of the SLQ instrument in the context of Malaysian indigenous primary schools.

\section{Research Objectives}

a. Identify the overall content validity of the SLQ instrument.

b. Identify the content validity of each item and dimension of the SLQ instrument.

c. Identify the reliability of SLQ instrument.

\section{Literature Review}

\section{A. Concept of Sustainable Leadership}

Hargreaves and Fink are two scholars who pioneered sustainable leadership in the education sector (Lambert, 2011) which is also one of the key sectors that need high quality and competent leaders. The Seven Principles of Sustainable Leadership introduced in 2003 by Hargreaves and Fink is the earliest model of sustainable leadership in the education sector (Hargreaves \& Fink, 2004). Then this model was refined and improved in 2006 (Hargreaves \& Fink, 2006).

Next, Fullan (2005) has introduced the Eight Elements of Sustainable Leadership. This followed by Davies (2009) and Lambert (2011) as well as many other scholars who have developed their respective models and frameworks of sustainable leadership especially for the field of education. In the education system especially in schools, headmasters often change due to promotion, retirement and even transfer. All this had an impact on students, teachers and even the school. Positive coordination of headmaster's movements across time and humans can maintain the sustainability in schools (Hargreaves \& Fink, 2006).

Sustainable leadership is broad and lasts for a long period of time; a shared responsibility; not wasting financial and human resources; maintaining the educational environment in organizations and communities; encouraging the exchange of ideas and good practices through collaborative learning (Hargreaves \& Fink, 2004). Meanwhile, Fullan (2005) argues that sustainable leadership is the ability of the entire system that includes tri-levels to achieve progress and continuous improvement based on moral goals. Related to this, sustainable leadership requires commitment from everyone from various levels in the organization for a culture of leadership to exist and be expanded (Lambert, 2011).

In short, the sustainable leadership of headmasters is (1) concerned with moral goals, (2) supporting collective learning among students, teachers and the community so that mutual success is achieved, (3) encouraging leadership among subordinates and (4) making it a culture for organizational sustainability achieved.

\section{B. Studies of Sustainable Leadership}

The literature of past studies in relation to sustainable leadership includes a case study by Nagy (2019) to identify the role of sustainable leadership in creating school culture as well as teacher-student relationships in South America. In this regard, Nagy reported that the principals in this study practised (1) a positive learning environment for all at school, (2) instilled a sense of belonging among everyone in the school at all times, (3) gave adequate autonomy, time and resources to the students and teachers to improve teaching and learning in schools, (4) prioritize the moral purpose of respecting and appreciating the services of teachers and (5) encourage and provide effective communication opportunities among teachers whether for academic or non-academic purposes in an effort to shape school culture and effective teacher-student relationships. 
In addition, two studies have been conducted in Thailand. First, Srisaen, Somprach and Junpeng (2017) conducted a study using the SEM method on 500 headmasters from high schools across Thailand to identify indicators of sustainable leadership in the schools. A second study was conducted to test the sustainable leadership practices of principals in 92 private schools involving 331 teachers (Agsonsua et al., 2019). The results showed that the practice of continuous learning is a practice that is often applied by principals in both studies.

Furthermore, a study on critical success factors of sustainable leadership from the teachers' perspectives was conducted by Yaakob et al (2020). This research was based on Sustainable Leadership Model by Fullan (2005) and utilised a combined quantitative and qualitative design approach (mixed method). The study which involved 629 respondents from 42 high schools in Malaysia showed that the sustainable leadership practices of principals were at a high level with mean scores between 4.60 to 4.37 . The dimension of focus on pupils recorded the highest mean score of 4.60 . These findings proved that the principals in excellent schools were always implemented sustainable leadership practices in carrying out their responsibilities.

In conclusion, the results of past studies provide a detailed explanation of the sustainable leadership practices of headmasters as chief administrators in schools. In this regard, it can be summarized that sustainable headmasters (1) give priority to deep and continuous learning practices in schools, (2) strive to produce successors for future leadership among teachers in schools, (3) promote a culture of collaboration in schools, (4) working with others especially teachers to sustain the excellence of the school.

\section{Research Methodology}

This quantitative study involved 6 experts to validate the content of the instrument adapted in this research. A survey was conducted in 4 indigenous primary schools located in Negeri Sembilan, Malaysia. The study involved a total of 50 teachers who were selected using the simple random method. The Sustainable Leadership Questionnaire (SLQ) instrument by Hardie (2011) was used to assess the respondents' (teachers') perceptions of sustainable leadership practices as practised by headmasters in the schools. This instrument was based on Eight Elements Model of Sustainable Leadership by Fullan (2005). All items were measured using a 5-point likert scale because this scale is suitable for measuring human attitudes (Cohen et al., 2018; Magotra et al., 2016). The summary of SLQ instrument is shown in Tables 1 below. 
Table 1

Summary of SLQ Instrument

\begin{tabular}{lll}
\hline Dimension & Items & Description \\
\hline Doing What's Right for Students & $1-6$ & $\begin{array}{l}\text { Set appropriate standards to be achieved by } \\
\text { students to reducing the achievement gap } \\
\text { between students. }\end{array}$
\end{tabular}

Taking the Long-Term View 7-10 Without Sacrificing Immediate Goals

Encouraging Peers to Learn from 11-16 Peers

Maintaining a Cycle of Positive Energy

Deepening Learning About 21-26 Instruction

Developing Leadership in Others

Changing the Work Context and Culture

Working Together to Address $37-40$ Accountability
Achieving short-term goals is important to gain the trust and support of all parties, especially students and teachers to achieve the vision and mission of the school in the long run.

Provide a conducive environment to promote effective communication among teachers to help improve the knowledge, skills and quality of teachers collectively through learning practices.

17-20 Maintain supportive professional relationships and always understand the emotions of others in the school to create a positive working environment.

Ensure the training and development of teachers is up-to-date and constructive to encourage instructional improvement among teachers to meet current educational needs.

27-30 Distribute leadership power to the teachers in the school according to their skills and competencies to ensure that the school system functions more efficiently.

31-36 Transform the school as a learning organization so that the achievements of students, teachers and schools are obtained and sustained.

Collaborate and communicate effectively with all parties to solve problems that arise in the school and achieved success.

Hardie (2011) 


\section{A. Content Validity}

The instrument used in this study were submitted to field experts for review to ensure that the content is appropriate and can measure the objectives of the study (Heale \& Twycross, 2015; Souza et al., 2017) after the translation and adaptation process had been completed. This is because the content validation of instrument is a key component in research and requires high-quality measurements. In this regard, measuring the value of the Content Validity Index (CVI) is the right choice to validate the content of the instrument. As a result of this, CVI values can be calculated for each item on one scale (known as the I-CVI) and for the overall scale (which we refer to as the S-CVI) (Polit \& Beck, 2006; Polit, Beck, \& Owen, 2007).

Firstly, an I-CVI value of 0.78 or higher for three or more experts can be considered as 'excellent' content validity. Meanwhile, the I-CVI achievement of 0.67 is still seen as 'fair'. Secondly, an S-CVI of 0.90 or higher for three or more experts can be considered 'excellent' content validity (Polit \& Beck, 2006; Polit, Beck, \& Owen, 2007). Thirdly, the kappa coefficient index also an important additional component for CVI because kappa values provide information on the level of expert agreement. Thus, in this study the modified kappa statistic coefficient index was used to determine the value of the kappa coefficient for the items (Polit et al., 2007) in the SLQ instrument.

In relation to this, a total of 6 experts were involved to validate the content of the instrument that were used in this study. The experts panel consists of 5 lecturers who are experienced in the field of educational leadership from Malaysian public universities and another lecturer who serves at the Institut Aminuddin Baki (main educational management institute in Malaysia). These six experts examined and evaluated all items using a four-point scale (Polit \& Beck, 2006; Polit et al., 2007). The evaluation scores that have been given by all experts on the items of sustainable leadership are shown in Tables 2 to 10 below.

Table 2

Content Validity of SLQ

\begin{tabular}{lccccccc}
\hline Expert & $\begin{array}{c}\text { Expe } \\
\text { rt }\end{array}$ & $\begin{array}{c}\text { Expe } \\
\text { rt }\end{array}$ & $\begin{array}{c}\text { Expe } \\
\text { rt 3 }\end{array}$ & $\begin{array}{c}\text { Expe } \\
\text { rt }\end{array}$ & $\begin{array}{c}\text { Expe } \\
\text { rt }\end{array}$ & $\begin{array}{c}\text { Expe } \\
\text { rt }\end{array}$ & $\begin{array}{c}\text { Cumulat } \\
\text { ive }\end{array}$ \\
& $\mathbf{1}$ & $\mathbf{2}$ & & $\mathbf{4}$ & $\mathbf{5}$ & $\mathbf{6}$ & \\
\hline Expert & $40 / 4$ & $37 / 4$ & $39 / 4$ & $40 / 4$ & $40 / 4$ & $34 / 4$ & $230 / 240$ \\
Agreeme & 0 & 0 & 0 & 0 & 0 & 0 & \\
nt & & & & & & & \\
\hline Expert & 100 & $93 \%$ & $98 \%$ & 100 & 100 & $85 \%$ & $96 \%$ \\
Agreeme & $\%$ & & & $\%$ & $\%$ & & \\
nt & & & & & & & \\
$(\%)$ & & & & & & & \\
\hline
\end{tabular}


INTERNATIONAL JOURNAL OF ACADEMIC RESEARCH IN PROGRESSIVE EDUCATION AND

DEVELOPMENT

Vol. 11, No. 1, 2022, E-ISSN: 2226-6348 @ 2022 HRMARS

Table 3

Dimension: Doing What's Right for Students

\begin{tabular}{|c|c|c|c|c|c|c|c|c|c|c|}
\hline $\begin{array}{l}\text { Ite } \\
\text { ms }\end{array}$ & $\begin{array}{c}\text { Ex } \\
p \\
1\end{array}$ & $\begin{array}{l}\text { Ex } \\
\text { p } 2\end{array}$ & $\begin{array}{c}\text { Ex } \\
\text { p } 3\end{array}$ & $\begin{array}{l}\text { Ex } \\
\text { p } 4\end{array}$ & $\begin{array}{c}\text { Ex } \\
\text { p } 5\end{array}$ & $\begin{array}{l}\text { Ex } \\
\text { p } 6\end{array}$ & $\begin{array}{c}\text { No. in } \\
\text { agreem } \\
\text { ent }\end{array}$ & $\begin{array}{c}\text { I- } \\
\text { CV } \\
\text { I }\end{array}$ & Pc & $\begin{array}{c}\text { Kappa } \\
\text { statist } \\
\text { ic }\end{array}$ \\
\hline \multirow[t]{2}{*}{1} & 1 & 1 & 1 & 1 & 1 & 1 & & 1.0 & .01 & \\
\hline & & & & & & & 6 & 0 & 6 & 1.00 \\
\hline \multirow[t]{2}{*}{2} & 1 & 1 & 1 & 1 & 1 & 1 & 6 & 1.0 & .01 & \\
\hline & & & & & & & & 0 & 6 & 1.00 \\
\hline \multirow[t]{2}{*}{3} & 1 & 1 & 1 & 1 & 1 & 1 & 6 & 1.0 & .01 & \\
\hline & & & & & & & & 0 & 6 & 1.00 \\
\hline \multirow[t]{2}{*}{4} & 1 & 1 & 1 & 1 & 1 & 1 & & 1.0 & .01 & \\
\hline & & & & & & & 6 & 0 & 6 & 1.00 \\
\hline \multirow[t]{2}{*}{5} & 1 & 1 & 1 & 1 & 1 & 1 & 6 & 1.0 & .01 & \\
\hline & & & & & & & & 0 & 6 & 1.00 \\
\hline \multirow[t]{2}{*}{6} & 1 & 1 & 1 & 1 & 1 & 0 & 5 & 0.8 & .09 & \\
\hline & & & & & & & & 3 & 4 & 0.81 \\
\hline
\end{tabular}

$\mathrm{S}-\mathrm{CVI} /$ Ave $=0.97$ (accepted); I-CVI = item content validity index; S-CVI = scale content validity index; $\mathrm{Pc}=$ Probability of chance agreement.

Table 4

Dimension: Taking the Long-Term View Without Sacrificing Immediate Goals

\begin{tabular}{|c|c|c|c|c|c|c|c|c|c|c|}
\hline $\begin{array}{l}\text { Ite } \\
\text { ms }\end{array}$ & $\begin{array}{c}\text { Ex } \\
p \\
1\end{array}$ & $\begin{array}{l}\text { Ex } \\
\text { p2 }\end{array}$ & $\begin{array}{l}\text { Ex } \\
\text { p } 3\end{array}$ & $\begin{array}{l}\text { Ex } \\
\text { p } 4\end{array}$ & $\begin{array}{l}\text { Ex } \\
\text { p } 5\end{array}$ & $\begin{array}{l}\text { Ex } \\
\text { p } 6\end{array}$ & $\begin{array}{c}\text { No. in } \\
\text { agreem } \\
\text { ent }\end{array}$ & $\begin{array}{l}\text { I- } \\
\text { CV } \\
\text { I }\end{array}$ & Pc & $\begin{array}{c}\text { Kapp } \\
\text { a } \\
\text { statis } \\
\text { tic }\end{array}$ \\
\hline 7 & 1 & 1 & 1 & 1 & 1 & 1 & & 1.0 & .01 & \\
\hline & & & & & & & 6 & 0 & 6 & 1.00 \\
\hline 8 & 1 & 1 & 1 & 1 & 1 & 1 & 6 & $\begin{array}{c}1.0 \\
0\end{array}$ & $\begin{array}{l}.01 \\
6\end{array}$ & 1.00 \\
\hline 9 & 1 & 1 & 1 & 1 & 1 & 1 & 6 & $\begin{array}{c}1.0 \\
0\end{array}$ & $\begin{array}{l}.01 \\
6\end{array}$ & 1.00 \\
\hline 10 & 1 & 1 & 1 & 1 & 1 & 1 & 6 & 1.0 & .01 & \\
\hline
\end{tabular}

$\mathrm{S}-\mathrm{CVI} /$ Ave $=1.00$ (accepted); I-CVI = item content validity index; S-CVI = scale content validity index; $\mathrm{Pc}=$ Probability of chance agreement. 
INTERNATIONAL JOURNAL OF ACADEMIC RESEARCH IN PROGRESSIVE EDUCATION AND

DEVELOPMENT

Vol. 11 , No. 1, 2022, E-ISSN: 2226-6348 @ 2022 HRMARS

Table 5

Dimension: Encouraging Peers to Learn from Peers

\begin{tabular}{|c|c|c|c|c|c|c|c|c|c|c|}
\hline Items & $\begin{array}{c}\text { Exp } \\
1\end{array}$ & $\begin{array}{c}\text { Exp } \\
2\end{array}$ & $\begin{array}{c}\text { Exp } \\
3\end{array}$ & $\begin{array}{c}\text { Exp } \\
4\end{array}$ & $\begin{array}{c}\text { Exp } \\
5\end{array}$ & $\begin{array}{c}\text { Exp } \\
6\end{array}$ & $\begin{array}{c}\text { No. in } \\
\text { agreement }\end{array}$ & $\begin{array}{c}\text { I- } \\
\text { CVI }\end{array}$ & Pc & $\begin{array}{c}\text { Kappa } \\
\text { statistic }\end{array}$ \\
\hline 11 & 1 & 1 & 1 & 1 & 1 & 0 & 5 & 0.83 & .094 & 0.81 \\
\hline 12 & 1 & 1 & 1 & 1 & 1 & 1 & 6 & 1.00 & .016 & 1.00 \\
\hline 13 & 1 & 1 & 1 & 1 & 1 & 0 & 5 & 0.83 & .094 & 0.81 \\
\hline 14 & 1 & 1 & 1 & 1 & 1 & 1 & 6 & 1.00 & .016 & 1.00 \\
\hline 15 & 1 & 1 & 1 & 1 & 1 & 1 & 6 & 1.00 & .016 & 1.00 \\
\hline 16 & 1 & 1 & 1 & 1 & 1 & 0 & 5 & 0.83 & .094 & 0.81 \\
\hline
\end{tabular}

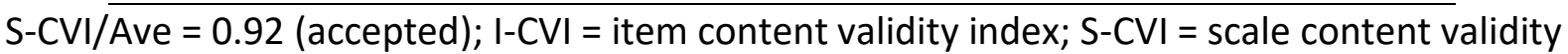
index; $\mathrm{Pc}=$ Probability of chance agreement.

Table 6

Dimension: Maintaining a Cycle of Positive Energy

\begin{tabular}{ccccccccccc}
\hline Items & $\begin{array}{c}\text { Exp } \\
\text { Exp }\end{array}$ & $\operatorname{Exp}$ & $\operatorname{Exp}$ & $\operatorname{Exp}$ & Exp & No. in & I- & Pc & Kappa \\
& $\mathbf{1}$ & $\mathbf{2}$ & $\mathbf{3}$ & $\mathbf{4}$ & $\mathbf{5}$ & $\mathbf{6}$ & agreement & CVI & & statistic \\
\hline 17 & 1 & 1 & 0 & 1 & 1 & 0 & 4 & 0.67 & .234 & 0.57 \\
18 & 1 & 1 & 1 & 1 & 1 & 1 & 6 & 1.00 & .016 & 1.00 \\
19 & 1 & 1 & 1 & 1 & 1 & 1 & 6 & 1.00 & .016 & 1.00 \\
20 & 1 & 1 & 1 & 1 & 1 & 1 & 6 & 1.00 & .016 & 1.00 \\
\hline
\end{tabular}

$\mathrm{S}-\mathrm{CVI} /$ Ave $=0.92$ (accepted); I-CVI = item content validity index; $\mathrm{S}-\mathrm{CVI}=$ scale content validity index; $\mathrm{Pc}=$ Probability of chance agreement.

Table 7

Dimension: Deepening Learning About Instruction

\begin{tabular}{ccccccccccc}
\hline Items & $\begin{array}{ccccc}\text { Exp } \\
\mathbf{1}\end{array}$ & $\mathbf{E}$ & $\mathbf{3}$ & $\mathbf{4}$ & $\mathbf{5}$ & $\mathbf{6}$ & $\begin{array}{c}\text { No. in } \\
\text { agreement }\end{array}$ & $\begin{array}{c}\text { I- } \\
\text { CVI }\end{array}$ & Pc & $\begin{array}{c}\text { Kappa } \\
\text { statistic }\end{array}$ \\
\hline 21 & 1 & 1 & 1 & 1 & 1 & 1 & 6 & 1.00 & .016 & 1.00 \\
22 & 1 & 1 & 1 & 1 & 1 & 1 & 6 & 1.00 & .016 & 1.00 \\
23 & 1 & 1 & 1 & 1 & 1 & 1 & 6 & 1.00 & .016 & 1.00 \\
24 & 1 & 1 & 1 & 1 & 1 & 1 & 6 & 1.00 & .016 & 1.00 \\
25 & 1 & 0 & 1 & 1 & 1 & 0 & 4 & 0.67 & .234 & 0.57 \\
26 & 1 & 1 & 1 & 1 & 1 & 1 & 6 & 1.00 & .016 & 1.00 \\
\hline
\end{tabular}

$\mathrm{S}-\mathrm{CVI} /$ Ave $=0.94$ (accepted) $; \mathrm{I}-\mathrm{CVI}=$ item content validity index; $\mathrm{S}-\mathrm{CVI}=$ scale content validity index; $\mathrm{Pc}=$ Probability of chance agreement.

Table 8

Dimension: Developing Leadership in Others

\begin{tabular}{ccccccccccc}
\hline Items & $\begin{array}{c}\text { Exp } \\
\text { Exp }\end{array}$ & $\begin{array}{c}\text { Exp } \\
\text { Exp }\end{array}$ & $\begin{array}{ccccc}\text { Exp } \\
\text { Exp }\end{array}$ & $\begin{array}{c}\text { No. in } \\
\text { agreement }\end{array}$ & $\begin{array}{c}\text { I- } \\
\text { CVI }\end{array}$ & Pc & $\begin{array}{c}\text { Kappa } \\
\text { statistic }\end{array}$ \\
\hline 27 & 1 & 1 & 1 & 1 & 1 & 1 & 6 & 1.00 & .016 & 1.00 \\
28 & 1 & 1 & 1 & 1 & 1 & 1 & 6 & 1.00 & .016 & 1.00 \\
29 & 1 & 1 & 1 & 1 & 1 & 1 & 6 & 1.00 & .016 & 1.00 \\
30 & 1 & 1 & 1 & 1 & 1 & 1 & 6 & 1.00 & .016 & 1.00 \\
\hline
\end{tabular}

$\mathrm{S}-\mathrm{CVI} /$ Ave $=1.00$ (accepted) $; \mathrm{I}-\mathrm{CVI}=$ item content validity index; $\mathrm{S}-\mathrm{CVI}=$ scale content validity index; $\mathrm{Pc}=$ Probability of chance agreement. 
INTERNATIONAL JOURNAL OF ACADEMIC RESEARCH IN PROGRESSIVE EDUCATION AND

DEVELOPMENT

Vol. 11, No. 1, 2022, E-ISSN: 2226-6348 @ 2022 HRMARS

Table 9

Dimension: Changing the Work Context and Culture

\begin{tabular}{ccccccccccc}
\hline Items & $\begin{array}{ccccc}\text { Exp } \\
\text { Exp }\end{array}$ & $\begin{array}{ccccc}\text { Exp } \\
\text { Exp }\end{array}$ & $\begin{array}{c}\text { Exp } \\
\mathbf{1}\end{array}$ & $\mathbf{E x p}$ & $\begin{array}{c}\text { No. in } \\
\text { agreement }\end{array}$ & $\begin{array}{c}\text { I- } \\
\text { CVI }\end{array}$ & Pc & $\begin{array}{c}\text { Kappa } \\
\text { statistic }\end{array}$ \\
\hline 31 & 1 & 0 & 1 & 1 & 1 & 1 & 5 & 0.83 & .094 & 0.81 \\
32 & 1 & 1 & 1 & 1 & 1 & 1 & 6 & 1.00 & .016 & 1.00 \\
33 & 1 & 1 & 1 & 1 & 1 & 1 & 6 & 1.00 & .016 & 1.00 \\
34 & 1 & 1 & 1 & 1 & 1 & 1 & 6 & 1.00 & .016 & 1.00 \\
35 & 1 & 0 & 1 & 1 & 1 & 1 & 5 & 0.83 & .094 & 0.81 \\
36 & 1 & 1 & 1 & 1 & 1 & 1 & 6 & 1.00 & .016 & 1.00
\end{tabular}

$\mathrm{S}-\mathrm{CVI} /$ Ave $=0.94$ (accepted) $; \mathrm{I}-\mathrm{CVI}=$ item content validity index; $\mathrm{S}-\mathrm{CVI}=$ scale content validity index; $\mathrm{Pc}=$ Probability of chance agreement.

Table 10

Dimension: Working Together to Address Accountability

\begin{tabular}{|c|c|c|c|c|c|c|c|c|c|c|}
\hline Items & $\begin{array}{c}\text { Exp } \\
1\end{array}$ & $\begin{array}{c}\text { Exp } \\
2\end{array}$ & $\begin{array}{c}\text { Exp } \\
3\end{array}$ & $\begin{array}{c}\text { Exp } \\
4\end{array}$ & $\begin{array}{c}\text { Exp } \\
5\end{array}$ & $\begin{array}{c}\text { Exp } \\
6\end{array}$ & $\begin{array}{c}\text { No. in } \\
\text { agreement }\end{array}$ & $\begin{array}{c}\text { I- } \\
\text { CVI }\end{array}$ & Pc & $\begin{array}{c}\text { Kappa } \\
\text { statistic }\end{array}$ \\
\hline 37 & 1 & 1 & 1 & 1 & 1 & 1 & 6 & 1.00 & .016 & 1.00 \\
\hline 38 & 1 & 1 & 1 & 1 & 1 & 1 & 6 & 1.00 & .016 & 1.00 \\
\hline 39 & 1 & 1 & 1 & 1 & 1 & 1 & 6 & 1.00 & .016 & 1.00 \\
\hline 40 & 1 & 1 & 1 & 1 & 1 & 1 & 6 & 1.00 & .016 & 1.00 \\
\hline
\end{tabular}

$\mathrm{S}-\mathrm{CVI} /$ Ave $=1.00$ (accepted) $; \mathrm{I}-\mathrm{CVI}=$ item content validity index; $\mathrm{S}-\mathrm{CVI}=$ scale content validity index; $\mathrm{Pc}=$ Probability of chance agreement.

Table 2 shows the agreement of the experts who evaluated the SLQ instrument which were adapted in this study. A total of 3 experts agreed $100 \%$. Meanwhile, expert 3 agreed with a $98 \%$ rate, expert 2 with a rate of $93 \%$ and expert 6 agreed with $85 \%$. Overall, all experts agreed $96 \%$ with the adaptation of this SLQ instrument. According to McHugh (2012) and Graham, Milanowski and Miler (2012) the instrument that achieved an expert agreement (inter-rater agreement) more than $80 \%$ is suitable to be used for the purpose of actual study. Thus, this SLQ instrument has been fully accepted in the context of this study.

Table 3 to 10 above describe the I-CVI values achieved for all 40 items by dimension. The results found that the I-CVI values of the items in the SLQ instrument were in the range of 0.67 to 1.00 . Most of the items in this instrument had reached the 'excellent' level and were acceptable because the I-CVI of each item exceeded 0.78 . As items that recorded an ICVI of 0.50 or less were not acceptable and should be rejected, then items 17 and 25 which had achieved an $\mathrm{I}-\mathrm{CVI}=0.67$ were still accepted with improvements in the sentence structure and had been tested for reliability.

Next, the S-CVI/Ave values for the eight dimensions ranged from 0.92 to 1.00 . The S-CVI value for dimension (a) Doing What's Right for Students is 0.97, (b) Taking the Long-Term View Without Sacrificing Immediate Goals at 1.00, (c) Encouraging Peers to Learn from Peers at 0.92, (d) Maintaining a Cycle of Positive Energy at 0.92, (e) Deepening Learning About Instruction is 0.94 , (f) Developing Leadership in Others is 1.00 , (g) Changing the Work Context and Culture at 0.94 and (h) Working Together to Address Accountability is 1.00 . Thus, all items in these dimensions were also fully accepted and retained because their values exceeded 0.90 (Polit \& Beck, 2006; Polit et al., 2007). 
In addition, the value of the modified kappa statistic achieved in this study was also 'excellent' because all 38 items were in the range of 0.81 to 1.00 for the six experts. Meanwhile, two more items recorded the modified kappa index at a 'fair' level (Polit et al., 2007). Overall, all items in this instrument had high content validity and were fully accepted in the context of this study.

\section{B. Reliability}

In this study, the analysis of Cronbach's alpha values, Cronbach's Alpha if item Deleted, Interitem Correlation and Corrected Item-Total Correlation were conducted using IBM-SPSS version 25.0 to test the reliability of the SLQ.

Table 11

Reliability of SLQ Instrument

\begin{tabular}{|c|c|c|c|}
\hline Dimension & $\begin{array}{l}\text { Cronbach' } \\
\text { s Alpha if } \\
\text { item } \\
\text { Deleted }\end{array}$ & $\begin{array}{l}\text { Inter- } \\
\text { item } \\
\text { correlati } \\
\text { on }\end{array}$ & $\begin{array}{c}\text { Correcte } \\
\text { d item- } \\
\text { Total } \\
\text { Correlati } \\
\text { on }\end{array}$ \\
\hline $\begin{array}{l}\text { Doing What's Right for } \\
\text { Students }\end{array}$ & $\begin{array}{c}.876 \text { to } \\
.897\end{array}$ & $\begin{array}{l}.461 \text { to } \\
.777\end{array}$ & $\begin{array}{l}.663 \text { to } \\
.803\end{array}$ \\
\hline $\begin{array}{l}\text { Taking the Long-Term View } \\
\text { Without Sacrificing } \\
\text { Immediate Goals }\end{array}$ & $\begin{array}{l}.851 \text { to } \\
.889\end{array}$ & $\begin{array}{l}.637 \text { to } \\
.799\end{array}$ & $\begin{array}{l}.752 \text { to } \\
.857\end{array}$ \\
\hline $\begin{array}{l}\text { Encouraging Peers to Learn } \\
\text { from Peers }\end{array}$ & $\begin{array}{l}.874 \text { to } \\
.889\end{array}$ & $\begin{array}{l}.481 \text { to } \\
.705\end{array}$ & $\begin{array}{l}.695 \text { to } \\
.773\end{array}$ \\
\hline $\begin{array}{l}\text { Maintaining a Cycle of } \\
\text { Positive Energy }\end{array}$ & $\begin{array}{c}.863 \text { to } \\
.901\end{array}$ & $\begin{array}{l}.641 \text { to } \\
.785\end{array}$ & $\begin{array}{l}.765 \text { to } \\
.872\end{array}$ \\
\hline $\begin{array}{l}\text { Deepening Learning About } \\
\text { Instruction }\end{array}$ & $\begin{array}{l}.875 \text { to } \\
.900\end{array}$ & $\begin{array}{l}.462 \text { to } \\
.746\end{array}$ & $\begin{array}{l}.643 \text { to } \\
.814\end{array}$ \\
\hline $\begin{array}{l}\text { Developing Leadership in } \\
\text { Others }\end{array}$ & $\begin{array}{l}.830 \text { to } \\
.903\end{array}$ & $\begin{array}{c}.484 \text { to } \\
.807\end{array}$ & $\begin{array}{l}.656 \text { to } \\
.852\end{array}$ \\
\hline $\begin{array}{l}\text { Changing the Work Context } \\
\text { and Culture }\end{array}$ & $\begin{array}{l}.921 \text { to } \\
.930\end{array}$ & $\begin{array}{c}.614 \text { to } \\
.921\end{array}$ & $\begin{array}{l}.788 \text { to } \\
.857\end{array}$ \\
\hline $\begin{array}{l}\text { Working Together to Address } \\
\text { Accountability }\end{array}$ & $\begin{array}{l}.908 \text { to } \\
.936\end{array}$ & $\begin{array}{l}.727 \text { to } \\
.860\end{array}$ & $\begin{array}{l}.816 \text { to } \\
.903\end{array}$ \\
\hline
\end{tabular}

The results of the analysis proved that the Cronbach's Alpha for the sustainable leadership practices of headmasters from the perspective of the teachers in this study had reached a value of .984 for a total of 40 items. Since the Cronbach's Alpha value which had been recorded was above 0.7 , this proved that the SLQ instrument in the context of this study had 
DEVELOPMENT

Vol. 11, No. 1, 2022, E-ISSN: 2226-6348 @ 2022 HRMARS

high reliability (Hair, Black, Babin, \& Anderson, 2019; Creswell \& Creswell, 2018). Next, Cronbach's Alpha if Item Deleted also recorded a value between .830 to .936 . This means that all items were highly appropriate and need to be retained because deleting any items in dimensions could further lower the Cronbach's Alpha value.

Furthermore, the analysis of the Inter-Item Correlation showed that all items in the SLQ recorded values between .461 to .921 . This proved the existence of a good correlation between items. Therefore, all items in this instrument were accepted because their value exceeded 0.30 (Hair et al., 2019).

Finally, acceptable Corrected Item-Total Correlation value is (1) more than 0.50 (Hair et al., 2019) and (2) range of 0.30 to 0.70 (De Vaus, 2004) to assess the correlation of items with the summation scale. The findings of this study showed that the value of Corrected Item-Total Correlation ranged from .643 to .903. So, each item in this SLQ instrument had a good correlation with constructs and dimensions.

\section{Discussion}

The analysis of I-CVI, S-CVI and modified kappa index showed that these items contributed to the consistency of the SLQ instrument in the context of this study. Furthermore, Cronbach's Alpha, Cronbach's Alpha if Item Deleted, Inter -Item Correlation and Corrected Item -Total Correlation also indicated that this instrument had high reliability and were suitable for the use of actual study.

Moreover, the literature found that the internal consistency (Cronbach's alpha) of the SLQ instrument in this study was high at .984 compared to scores recorded in previous study by Yaakob et al (2020) with 629 respondents in Malaysia at 0.954 . Thus, the analysis supported study by Fullan (2005) and Hardie (2011) which stated that the eight dimensions in this study had equal importance on sustainable leadership practices among headmasters in schools.

The findings of this study contribute to three main implications. First, study have proven that SLQ instrument had high validity and reliability. In other words, this instrument had been certified suitable for testing in primary schools. Second, it is undeniable that in recent times the concept of sustainable leadership of headmasters has become increasing in popularity and discussed and studied by various stakeholders in the field of education. Thus, this study contributes to the development of the literature on the sustainable leadership practices of headmasters in schools. Third, the findings of this study provide awareness to the headmasters to practise sustainable leadership practices in schools to improve the school effectiveness. This is because it was found that sustainable leadership practices by headmasters promised the achievement and excellence of the school for the long term (Conway, 2015).

\section{Recommendation and Conclusion}

This pilot study was conducted in four indigenous primary schools. Therefore, it is suggested that further research can be implemented by using optimal amount of data to ensure that generalizations can be made about the findings of the study. Other than that, various validity and reliability test also can be conducted. In addition, other quantitative analysis techniques such as exploratory factor analysis (EFA) and confirmatory factor analysis (CFA) can employed for better instrument validity and reliability to confirmed that the SLQ instrument has high stability. 
DEVELOPMENT

Vol. 11, No. 1, 2022, E-ISSN: 2226-6348 @ 2022 HRMARS

As a conclusion, we strongly agreed that the headmasters' sustainable leadership practices in every school should be prioritized to ensure that the quality of (1) students, (2) teachers and the (3) schools can be improved.

\section{Corresponding Author}

Saraswathy Kullan

Email: saraswathy_kullan@yahoo.com

\section{References}

Agsonsua, P., Kositpimanwech, E., \& Yuenyong, C. (2019). Examining existing ideas about sustainable leadership of private school science principals. Journal of Physics, 1340. https://doi.org/10.1088/1742-6596/1340/1/012041

Cohen, L., Manion, L., \& Morrison, K. (2018). Research Methods in Education (8 ${ }^{\text {th }}$ edition). New York: Routledge.

Conway, J. M. (2015). Sustainable leadership for sustainable school outcomes: Focusing on the capacity building of school leadership. Leading \& Managing, 21(2), 29-45.

Creswell, J. W., \& Creswell, J. D. (2018). Research Design: Qualitative, Quantitative, and Mixed Methods Approaches ( $5^{\text {th }}$ ed). Thousand Oaks, California: SAGE Publications, Inc.

Davies, B. (2009). The essentials of school leadership. London, Sage.

Dueppen, E. J. (2017). Sustainable leadership: A case study examining perceptions of participants in a long-term, district-wide reform. Unpublished doctoral dissertation, Arizona: Northern Arizona University. Available from ProQuest Dissertations and Theses database.

De Vaus, D. (2004). Surveys in Social Research (5 $5^{\text {th }}$ ed.). London: Routledge.

D’Innocenzo, L., Mathieu, J. E., \& Kukenberger, M. R. (2016). “A meta-analysis of different forms of shared leadership-team performance relations". Journal of management, 42(7), 1964-1991.

Fullan, M. (2005). Leadership \& Sustainability: System Thinkers in Action. Thousand Oaks, CA: Corwin Press.

Fullan, M. (2008). What's Worth Fighting for in the Principalship? (2 ${ }^{\text {nd }}$ ed.) New York, NY: Teacher College Press/Ontario Principal's Council.

Graham, M., Milanowski, A., Miler, J. (2012). Measuring and Promoting Inter-Rater Agreement of Teacher and Principal Performance Ratings. Center for Educator Compensation Reform, 1-33.

Hargreaves, A., \& Fink, D. (2006). Sustainable Leadership. San Francisco, CA: Jossey-Bass.

Hargreaves, A., \& Fink, D. (2004). The Seven Principles of Sustainable Leadership. Educational Leadership: Journal of the Department of Supervision and Curriculum Development, N.E.A, 61(7), 8-13.

Hair, J. F., Black, W. C., Babin, B. J., \& Anderson, R. E. (2019). Multivariate data analysis (8 ${ }^{\text {th }}$ ed). UK: Cengage.

Hardie, R. A. (2011). Principals' Perceptions of the Essential Components of Sustainable Leadership and Implications for Succession Planning at the Elementary School Level: A Mixed Methods Research Study. Unpublished doctoral dissertation, Saskatoon: University of Saskatchewan. Retrieved from https://harvest.usask.ca/bitstream/handle/10388/ETD-2011-12-299/1_HARDIEDISSERTATION.pdf?isAllowed $=y \&$ sequence $=4$ 
Heale, R., \& Twycross, A. (2015). Validity and reliability in quantitative studies. Evid Based Nurs, 18(3), 66-68. https://doi.org/10.1136/eb-2015-102129

Iqbal, Q., Ahmad, N. H., \& Li, Y. (2021). Sustainable leadership in frontier Asia region: Managerial discretion and environmental innovation. Sustainability, 13. 5002. https://doi.org/10.3390/su13095002.

Li, J. L., Hallinger, P., \& Ko, J. (2016). Principal leadership and school capacity effects on teacher learning in Hong Kong. International Journal of Educational Management, 30(1), 76-100.

Leithwood, K., \& Azah, V. (2016). Characteristics of effective leadership networks. Journal of Educational Administration, 54(4), 409-433.

Lambert, S. (2011). Sustainable leadership and the implication for the general further education college sector education college sector. Journal of Further Higher Education, 35(1), 131-148. https://doi.org/10.1080/0309877X.2010.540319

Lambert, S. (2012). The perception and implementation of sustainable leadership strategies in further education colleges. Journal of Leadership Education, 11(2), 102-119.

Magotra, I., Sharma, J., \& Sharma, S. K. (2016). Assessing personal disposition of in dividuals towards technology adoption. Future Business Journal, 2(1), 81-101. https://doi.org/10.1016/j.fbj.2016.05.003

Mahzan, F. A., \& Nordin, N. M. (2021). The relationship between transformational leadership practiced and the level of job satisfaction among lecturers in MARA Professional College, Malaysia. The Journal of University Education (AJUE), 17(3), 154-161. https://doi.org/10.24191/ajue.v17i3.14511

McHugh, M. L. (2012). Interrater reliability: the kappa statistic. Biochemia Medica, 22(3), 276282

Ministry of Education Malaysia. (2018). Annual Report PPPM 2017. Putrajaya: MOE Malaysia. Retrieved from padu.edu.my

Nagy, S. J. (2019). Sense of belonging, school climate, and teacher-student relationship through sustainable leadership: An international case study. Unpublished doctoral dissertation, Virginia: George Mason University. Available from ProQuest Dissertations and Theses database.

OECD. (2016). School Leadership for Learning: Insights from TALIS 2013, TALIS. OECD Publishing, Paris. http://dx.doi.org/10.1787/9789264258341

Polit, D. F., \& Beck, C. T. (2006). The Content Validity Index: Are You Sure You Know What's Being Reported? Critique and Recommendations. Research in Nursing \& Health, 29, 489-497. https://doi.org/10.1002/nur

Polit, D. F., Beck, C. T., \& Owen, S. V. (2007). Is the CVI an acceptable indicator of content validity? Appraisal and recommendations. Research in Nursing \& Health. 30(4), 459467. https://doi.org/10.1002/nur.20199

Sezgin-Nartgun, S., Limon, I., \& Dikelci, U. (2019). The Relationship between Sustainable Leadership and Perceived School Effectiveness: The Mediating Role of Work Effort. Bartin University Journal of Faculty of Education, 9(1),141-154. https://doi.org/10.14686/buefad.653014

Srisaen, K., Somprach, K., \& Junpeng, P. (2017). Development of Sustainable Leadership Indicators for Basic Educational School Principals in Thailand. The Turkish Online Journal of Educational Technology, Special Issue, 897-904. 
Souza, A. C., Alexandre, N. M. C., \& Guirardello, E. B. (2017). Psychometric properties in instruments evaluation of reliability and validity. Brasilia, 26(3). https://doi.org/10.5123/S1679-49742017000300022

Taherdoost, H. (2016). Validity and reliability of the research instrument: How to test the validation of a questionnaire/survey in a research. International Journal of Academic Research in Management, 5(3), 28-36.

United Nations Educational, Scientific and Cultural Organization. (2018). Issues and trends in Education for Sustainable Development. Paris: France.

Vikaraman, S. S., Mansor, A. N., Nor, M. Y. M., Alia, B. S., \& Gurusamy, V. (2021). Ethical leadership practices and trust among public school leaders in Malaysia. The Journal of University Education (AJUE), $17(3)$, 174-191. https://doi.org/10.24191/ajue.v17i3.14509 